\title{
MAPS SHOWING AEROMAGNETIC SURVEY AND GEOLOGIC INTERPRETATION OF THE UGASHIK AND PART OF THE KARLUK QUADRANGLES, ALASKA
}

By

\author{
J. E. Case, R. L. Detterman, Frederic H. Wilson, Bruce A. Chuchel,
} and M. Elizabeth Yount

\section{INTRODUCTION}

Aeromagnetic surveys over the Ugashik and part of the Karluk quadrangles were flown in 1980 and 1982 as part of the Alaska Mineral Resource Assessment Program (AMRAP). Magnetic data provide information on the composition, structure, and three-dimensional geometry of major rock units and, hence, are useful in tracing geologic features that are covered by alluvium, water, and glacial deposits. Some rock units associated with metallic ore deposits or occurrences have characteristic magnetic expression; this expression, when used with geologic and geochemical data, may indicate areas that have potential for mineralization. The magnetic data also provide a means to estimate depth to basement and the configuration of sedimentary basins that also have potential for hydrocarbon resources.

This report includes the aeromagnetic map superimposed on the topographic base (sheet 1) and an interpretation map superimposed on the topography and simplified geology (sheet 2). The discussion provides an interpretation of the aeromagnetic data with respect to regional geology, occurrence of ore deposits and prospects, and potential oil and gas resources.

Data from several different sources were used in compilation of the residual aeromagnetic map. The principal data set derives from a survey completed in 1980 by Fugro Geometrics Inc. The survey covers an irregularly shaped area extending southwest-northeast across the central part of the Ugashik-Karluk region. Flight lines, spaced about $1 \mathrm{mi}$ apart, were flown in a northwest-southeast direction at a nominal height of $1,000 \mathrm{ft}$ above the ground surface. The International Geomagnetic Reference Field (IGRF) of 1975, updated to 1980 , was removed from the observed totalintensity magnetic field, and the data were computercontoured at scale 1:63,360 using a grid interval of $660 \times 660$ $\mathrm{ft}$ at intervals of 20,100 , and 500 gammas. An arbitrary constant value of 53,000 gammas was added to the field values. The original contour maps contained numerous highs and lows and linear steepened gradients parallel to and normal to the flight-line directions, perhaps because the grid interval was too small in comparison to flight-line spacing. A second major survey over the Bristol Bay lowlands (area A, sheet 1 ), in the vicinity of Alinchak Bay (area B), and near Mount Chiginagak and Chiginagak Bay (area C) was flown by Diversified Technical Services Inc. (U.S. Geological Survey, 1984). Flight lines were spaced at 1 to $2 \mathrm{mi}$ apart and were flown at about $1,000 \mathrm{ft}$ above the ground surface. IGRF of 1975 , updated to 1982 , was subtracted from the data, and a residual anomaly map was contoured by computer using a grid interval of $2,000 \mathrm{ft}$ and a contour interval of 50 gammas. Both of these surveys probably contain some errors in geographic location because of the rugged terrain and extremely bad weather, including fog and high winds. As a result of positional discrepancies and different contouring algorithms, anomalies shown on these two original data sets do not match in detail in some areas. The two data sets were merged by Frank Petrafeso (U.S. Geological Survey) as part of a compilation of a 1:1,000,000-scale magnetic anomaly map of Alaska. Values on both surveys were adjusted to a common datum (zero anomaly) compatible with data elsewhere in southern Alaska. A smoothed map at scale $1: 250,000$ and a contour interval of 200 gammas was provided for use in this report. We have added local 100-ga mma contours from the original maps in areas of lower magnetic gradients. Another source of data was a widely spaced survey by Andreasen and others (1963) in the area near Cape Igvak, which we have used to approximately locate contours near Mount Becharof. Comparison with the survey of the adjacent Chignik-Sutwik Island quadrangles to the south (Case and others, 1981) shows a fair to good positional correlation of anomalies.

In summary, magnetic anomalies determined by this study may be somewhat suspect with respect to detailed position and amplitude. This map should not be used for detailed geologic correlations or for prospecting purposes, but it is useful in defining regional geologic patterns and areas where more detailed geophysical surveys might be appropriate.

Because of the inclement weather and ruggedness of the central and southeast parts of the Alaska Peninsula, it was difficult for the aircraft to maintain a constant height of $1,000 \mathrm{ft}$ above the terrain, particularly across deep narrow valleys or narrow marine inlets. Therefore, some apparent magnetic anomalies are related to the geometry of the survey rather than to geologic features. More detailed discussions of anomalies related to drape-flying elsewhere in Alaska can be found in reports by Griscom (1975) and Case and others (1979), and a theoretical discussion has been provided by Grauch and Campbell (1984).

In some places, the original detailed aeromagnetic maps have a northwest-southeast grain parallel to the direction of the flight lines and a less prominent grain oriented northeastsouthwest. This apparent orthogonal pattern, in part, has an origin independent of geologic features: (1) the Earth's diurnal field may have changed significantly between flying adjacent lines, and (2) the algorithm used for the computercontouring process introduces spurious lineaments parallel to the orientation of the grid. These possibilities introduce interpretive difficulties regarding the presence or absence of magnetic expression of geologically significant lineaments, which may be related to northwest-trending segmentation of the volcanic arc that occurs along the Alaska Peninsula. We are confident that some of these lineaments, however, express geologic features, as discussed in a subsequent section.

\section{SUMMARY OF GEOLOGY}

Geologic descriptions of the Ugashik and Karluk quadrangles are provided in reports by Detterman and others $(1983,1986)$ and Burk (1965), and the generalized stratigraphy is shown on figure 1. Briefly, this segment of the Alaska Peninsula is dominated by Quaternary volcanic centers at Mount Yantarni, Mount Chiginagak, Mount Kialagvik, and Mount Peulik. Several smaller centers occur in the area, and material from Aniakchak Crater, just to the south in the Chignik quadrangle, covers large areas in the southern part of the Ugashik quadrangle.

Thick sequences of Quaternary deposits and Tertiary marine and nonmarine sedimentary rocks occur in one or more large basins along the Bristol Bay side of the peninsula and in smaller northeast-trending basins or synclines near Lower and Upper Ugashik Lakes and Becharof Lake. Lower Tertiary volcanic rocks and interstratified sedimentary rocks are exposed sporadically across much of the mountainous part of the area.

Permian limestone and Triassic limestone, limestone conglomerate, and basalt are exposed in a small area near Puale and Alinchak Bays. Marine and nonmarine Jurassic and 
Cretaceous clastic and carbonate strata form thick sequences exposed in the cores of northeast-trending, complexly-faulted anticlines. Folds are generally broad and open, and a major deformational event in the area occurred after deposition of the Bear Lake Formation (Miocene). Most faults are high angle, and northwest-dipping reverse faults have been mapped in the vicinity of Mount Chiginagak and northeast of Puale Bay. Major sets of northwest-trending faults occur in the central part of the area between Wide Bay and Becharof Lake, possibly related to transverse segmentation of the Alaska Peninsula.

Numerous late Tertiary dioritic to quartz dioritic plutons are scattered throughout the area and have associated copper and molybdenum mineralization of the porphyry type in both plutons and wallrocks. Hypabyssal intrusive centers are common and range from andesite to dacite in composition. Unless otherwise noted, ages of Cenozoic igneous rocks cited in this report were determined by $\mathrm{F}$. $\mathrm{H}$. Wilson using $\mathrm{K}-\mathrm{Ar}$ techniques. Detailed descriptions are provided in reports by Wilson $(1978,1980)$, Wilson and others (1981), Wilson and Shew (1982, in press).

\section{Magnetic basement}

In places magnetic anomalies are produced by rocks not exposed at the surface. The sources of the anomalies caused by this magnetic basement may be shallow or deep, depending on the thickness of relatively nonmagnetic cover. Estimates of depth can be made from the steepness of gradients along flight lines. The age and lithology of the magnetic basement are uncertain: in the nor theast part of the area near Puale Bay, Triassic limestones are intercalated with basaltic breccias, agglomerates, and sills that may produce magnetic anomalies. A single locality of mid-Permian limestones has also been reported near there (Hanson, 1957), so pre-Permian magnetic rocks could be sources of some anomalies. The Gulf Oil Corporation Port Heiden No. 1 drill hole near the northcentral edge of the adjacent Chignik-Sutwik Island area bottomed in granitic rocks of Jurassic age (Brockway, 1975; Reed and Lanphere, 1973) at a depth of about $15,000 \mathrm{ft}$. In the northwest part of the Ugashik-Karluk area, the General Petroleum Great Basins No. 1 bottomed in Jurassic granitic rocks (isotopic age, $177 \mathrm{Ma}$ ) at a depth of $11,080 \mathrm{ft}$, and the General Petroleum Great Basins No. 2 bottomed in undated granitic rocks at a depth of $8,865 \mathrm{ft}$ (Brockway, 1975). In the southwest part of the area, the City Service Corporation Painter Creek No. 1 hole bottomed in the Shelikof Formation of Middle Jurassic age at a depth of $8,000 \mathrm{ft}$ (Brockway, 1975). In the southeast part of the area, the Richfield Wide Bay Unit No. 1 drill hole penetrated a total of $12,566 \mathrm{ft}$, including Jurassic (about 1,000 feet), Triassic (about 7,500 ft), and Triassic or older deposits (about 4,000 ft) (Sweet, 1964, and drilling $\log$ ). In the east part of the area, the HumbleShell Bear Creek No. 1 unit bottomed at a depth of 14,374 $\mathrm{ft}$. It penetrated about $4,000 \mathrm{ft}$ of Upper Jurassic deposits, $5,750 \mathrm{ft}$ of Middle and Lower Jurassic deposits, and about $4,600 \mathrm{ft}$ of Triassic deposits (drilling $\log$ ).

Jurassic quartz diorite crops out on a small island near Gas Rocks in the south part of Becharof Lake. Elsewhere in the region, rocks of the Jurassic batholith are commonly magnetic (Reed and Lanphere, 1973; Reed and others, 1983; and Case and Nelson, 1986). Jurassic granitoid and volcanic rocks exposed to the north in the Naknek quadrangle produce ovoid magnetic highs of several hundred gammas (Andreasen and others, 1962).

Simple Bouguer anomalies range from about $-10 \mathrm{mGals}$ to $+40 \mathrm{mGals}$ in the area (Barnes, 1977). Such anomalies are not definitive of crustal type. On a larger regional scale, however, large positive anomalies ( +50 to $+100 \mathrm{mGals}$ ) suggest oceanic or transitional crust under the peninsula south of the Ugashik-Karluk area, and large negative anomalies (0 to -40 mGals) suggest transitional to continental values north of the area.

Thus, the magnetic basement in part may consist of Jurassic and (or) Cretaceous plutonic rocks and older rocks, especially in the northern part of the Ugashik quadrangle, and pre-Jurassic oceanic or transitional crust in the central and southern parts of the area.
A complicating factor about the age, depth, and composition of the magnetic basement of the area is that the Jurassic Naknek Formation (2,500 ft or more thick) is a highly magnetic unit in places, as discussed more fully in subsequent sections.

\section{SUSCEPTIBILITIES OF MAJOR ROCK GROUPS}

Magnetic susceptibilities have been measured on about 210 samples from the Ugashik, Karluk, Chignik, Sutwik Island, and adjacent quadrangles on the Alaska Peninsula by Robert Morin. Measured values for the Chignik and Sutwick Island area, previously tabulated by Case and others (1981), are included on the histogram shown on figure 2. Most samples are random grab samples collected during the course of geologic mapping, and they do not constitute a statistically significant sample of the magnetic properties of major rock units. However, the few measurements provide an approximation of the range of values of susceptibility and indicate expectable values for most rock units. In general, rocks producing significant magnetic anomalies, as measured at a height $1,000 \mathrm{ft}$ above the body, have susceptibilities greater than $\mathbf{0 . 0 0 0 5}$ centimeter-gram-second (cgs) units. Rocks having susceptibilities of less than $0.001 \mathrm{cgs}$ unit are regarded as weakly magnetic. Those having susceptibilites of 0.001-0.003 cgs units are moderately magnetic, producing anomalies of as much as several hundred gammas. Rocks having susceptibilities greater than $0.003 \mathrm{cgs}$ units are regarded as strongly magnetic and produce anomalies of several hundred gammas or more. Most sedimentary rocks have susceptibilities of less than $0.0002 \mathrm{cgs}$ units. The susceptibility measurements also indicate abnormally high values for many samples from the Naknek and Shelikof Formations of Jurassic age. Parts of these Jurassic sedimentary rocks produce large aeromagnetic anomalies.

No measurements of remanant magnetization have been made on any of the samples collected for this investigation. This parameter should be measured for complete analysis of the aeromagnetic anomalies. Paleomagnetic investigations elsewhere in the region have been described by various university investigators (Stone and Packer, 1979; Stone and others, 1982; Thrupp, 1984a,b; Thrupp and Coe, 1983; Coe and others, 1985; and Panuska and Stone, 1985). Remanent magnetizations that have been reported have an extremely wide range - from less than $1 \times 10^{-6} \mathrm{emu} / \mathrm{cm}^{3}$ to more than $368 \mathrm{emu} / \mathrm{cm}^{3}$. Remanent magnetization may be dominant for younger volcanic rocks.

\section{Jurassic sedimentary rocks}

The Shelikof Formation is a Callovian ammonitebearing volcanogenic clastic unit that is as much as $1,500 \mathrm{ft}$ or more thick. Several samples have susceptibilities of as much as $0.006 \mathrm{cgs}$ units, but most values are low, less than $0.0001 \mathrm{cgs}$ unit. The Tithonian to Oxfordian Naknek Formation appears to have been derived from erosion of the Jurassic part of the Alaska-Aleutian Range batholith. In the Ugashik and Karluk quadrangles, the general pattern of facies changes from thick conglomerates and crossbedded sandstones--perhaps continental--in the northwest to paralic and marine sandstones and siltstones in the southeast. Many of the crossbedded sandstones are rich in magnetite in keeping with their derivation from Jurassic granitoid plutons that are magnetite-rich elsewhere in Alaska (Reed and Lanphere, 1973; Case and Nelson, 1986). Susceptibilities of 25 samples range from 0 to $0.010 \mathrm{cgs}$ units, and 11 samples have values greater than $0.001 \mathrm{cgs}$ unit (fig. 2). The Naknek Formation, 3,000 to $8,000 \mathrm{ft}$ or more thick, is known to produce aeromagnetic anomalies in many places. The conglomeratic facies appears to be especially magnetic as judged from correlation of outcrops of the facies with the position of magnetic highs. Whether the magnetite-rich zones are accompanied by gold or other placer concentrates remains to be determined.

\section{Cretaceous and Tertiary sedimentary rocks}

Clastic rocks of the Cretaceous Hoodoo and Chignik 
Formations and the Tertiary Tolstoi and Stepovak Formations appear to be virtually nonmagnetic even though some of the deposits are of volcanic provenance. Susceptibilities of 23 samples are less than $0.0001 \mathrm{cg}$ units, and only one sample--a conglomerate containing volcanic clasts-has a susceptibility of more than $0.002 \mathrm{cgs}$ units.

\section{Tertiary intrusive rocks}

Batholiths, stocks, sills, and dikes of Tertiary age are abundant in the area, and most have granodioritic-dioritic to mafic compositions. Susceptibilities have a wide range -from less than 0.0001 to more than $0.007 \mathrm{cgs}$ units. Most are magnetic, having values of 0.001 to 0.003 cgs units. Many Tertiary plutons produce large positive magnetic anomalies, but magnetic anomalies are subdued where the rocks are altered.

\section{Tertiary volcanic rocks}

Lower Tertiary volcanic rocks tend to be basaltic to andesitic in composition. The average susceptibility of 49 samples is about $0.002 \mathrm{cgs}$ units, moderately magnetic.

\section{Quaternary volcanic rocks}

The Quaternary volcanic rocks tend to be andesitic to dacitic. Susceptibilities of 22 samples range from about 0.0001 to $0.004 \mathrm{cgs}$ units and average about $0.002 \mathrm{cgs}$ units, which is sufficient to produce many of the anomalies observed over the volcanic centers.

\section{INTERPRETATION OF AEROMAGNETIC ANOMALIES}

Five broad groups of anomalies are superimposed on the regional field; (1) Single anomalies or clusters of anomalies of moderately high amplitude and short wavelength are related to the young volcanic centers of Mount Chiginagak, Mount Kialagvik, Mount Peulik, and Mount Kejulik (a center just north of the map area). (2) Other groups of anomalies form oval or partly oval patterns over older volcanic-plutonic complexes near Chiginagak Bay, and similar complexes are interpreted to occur near Alinchak Bay. (3) Strongly positive oval anomalies occur over many exposed or shallow Tertiary plutons, such as those near the head of Port Wrangell. (4) Long-wavelength, high-amplitude anomalies that have gentle gradients reflect deep-seated features of the basement, possibly quartz diorite plutons, under the basin areas. (5) Elongate anomaly belts of high amplitude occur over Tertiary volcanic rocks, over some exposures of Jurassic conglomerates, and possibly over other magnetite-rich zones in sandstones of the Jurassic Naknek Formation.

In the following descriptions, groups of anomalies shown on the aeromagnetic map (sheet 1) are numbered on the interpretation map (sheet 2); the interpretive discussion is keyed to these numbers. Known or inferred rock types that may be sources for the anomalies are shown on the interpretive map also. Boundaries between areas are subjective and have been drawn near zones of steepened magnetic gradients that crudely define groups of anomalies. Locally, boundaries have been drawn that diverge from gradients in order to include rock units that have been mapped in the field.

Some of the larger and more conspicuous closed magnetic lows, which generally have an amplitude greater than -50 gammas, are indicated by hachured contours. The source of many lows cannot be determined from available data. Some lows may be produced by: (1) normal polarization, (2) effects of topography related to the drapeflying process or buried channels in the magnetic basement, (3) effects of alteration, or (4) reversed remanent magnetization. Only where the cause of the low can be postulated with some confidence has a source been assigned (see sheet 2). Identification of the sources of the anomalies is of special significance for two reasons: (1) if magnetic reversals are present over the flows of the younger volcanic centers, some of the rocks are probably older than $0.7 \mathrm{Ma}$, which is the approximate age of the first major magnetic reversal in the past; identification of reversals would have implications for the Quaternary magnetostratigraphy of the Alaska Peninsula; (2) if lows indicate areas of hydrothermal alteration, particularly areas associated with granodioritic plutons, they may be guides to ore mineralization. Only a few areas of suspected alteration have been added to the interpretive map. Other areas of known alteration are shown on the geologic map (sheet 2).

\section{Specific areas and anomalies}

\section{Bristol Bay lowlands}

Much of the Bristol Bay lowlands is underlain by a thick layered sequence of Tertiary sedimentary and volcanic rocks. The aeromagnetic anomalies and scant well data indicate that the layered sequence is underlain by moderately to strongly magnetic plutons, probably granitoid bodies of the Alaska-Aleutian Range batholith, which ranges from Jurassic to Tertiary in age.

Area 1 is characterized by anomalies that have low amplitudes and gentle magnetic gradients. The magnetic gradients indicate that the magnetic basement lies at 3 to 5 $\mathrm{km}$ or more beneath the flight elevation of the aircraft. This interpretation is supported by evidence from two drill holes (General Petroleum's Great Basins Nos. 1 and 2), which bottomed in granitoid rocks at about $11,080 \mathrm{ft}$ and $8,865 \mathrm{ft}$, respectively. No Tertiary volcanic rocks (Meshik Formation) have been reported from these wells, but they were encountered in adjacent areas. Small relative positive anomalies of about 50 to 100 gammas in areas 2 indicate weakly to moderately magnetic source rocks, probably granitoid plutons. Two large ovoid positive anomalies (areas 3 ) have amplitudes of about 400 to 500 gammas. Considering the depth to the sources, which is probably $3 \mathrm{~km}$ or more, the anomalies must be produced by strongly magnetic bodies. Although some granitoid plutonic rocks that crop out in the Lake Clark area to the northeast produce anomalies of similar magnitude (Case and Nelson, 1986), we believe that a more mafic and magnetic rock--perhaps a dioritic or gabbroic phase--should be considered as an equally possible source for the anomalies. The northern anomaly near Cape Greig is associated with a positive gravity anomaly of 10 to $20 \mathrm{mGals}$ (Barnes, 1977). Dioritic and small mafic and ultramafic bodies are exposed in the lliamna quadrangle along the Aleutian Range to the northeast (Detterman and Reed, 1980). Elsewhere, similar positive magnetic anomalies caused by deep-seated sources occur over the Cook Inlet basin and the Copper River basin where the deep sources have been interpreted to be related to mafic magmatism associated with tensional opening that formed the basins (Griscom and Case, 1982).

Smaller highs, ranging in amplitude from about 50 to 300 gammas, occur sporadically over the Bristol Bay lowlands (areas 4). The sources may be buried Tertiary or Quaternary volcanic rocks. The Great Basins Ugashik No. 1 well bottomed in volcanic rocks at a depth of $9,476 \mathrm{ft}$ after penetrating about $2,500 \mathrm{ft}$ of volcanic and volcaniclastic rocks. How ever, granitoid plutons at greater depth could be the source for some or all of the anomalies.

Quaternary volcanic rocks of the Blue Mountain region produce steep-gradient anomalies of more then $\mathbf{5 0 0}$ gammas in area 5. Magnetic lows on the northeast, east, and south sides of the Blue Mountain anomaly are probably edge or polarization lows related to the dipolar nature of magnetized objects. Other Quaternary volcanic rocks may produce small shallow-source anomalies (shown on more detailed maps (U.S. Geological Survey, 1984)) superimposed on deeper source anomalies, such as those in areas 3 and 4.

Magnetic highs in areas 6 , which range up to 600 gammas in amplitude, occur principally over Becharof Lake or over Quaternary sedimentary deposits; hence, their sources are unknown. Steep gradients on detailed maps (U.S. Geological Survey, 1984) indicate shallow burial; thus, either shallow intrusive or volcanic sources are most likely. Immediately to the south and east, however, Jurassic conglomerates and sandstones also produce elongate positive anomalies and could be a sedimentary source of the highs. 
Western zone, Aleutian Range

Along the southwest part of the western mountain front, anomalies ranging from 200 to 1,000 gammas in amplitude occur over a belt of Meshik volcanic rocks. In area $7 \mathrm{~A}$, the rocks strike northeast and dip northwest at 30 to $60^{\circ}$. In area $7 \mathrm{~B}$, strikes and dips indicate a poorly defined anticlinal nose (Detterman and others, 1983, 1986), and the pattern of magnetic anomalies is much less linear than in area $7 \mathrm{~A}$. If the structural geology shown is correct, then a northwest-trending fault probably occurs between the volcanic rocks of areas $7 \mathrm{~A}$ and $7 \mathrm{~B}$.

Small exposures of Meshik volcanic rocks near the City Service Painter Creek No.1 well have little expression on the magnetic map and hence are very thin or relatively nonmagnetic.

A prominent low is present along the northwest flank of anomaly area 7 . The low may be caused by reversed remanent magnetization as its amplitude is rather large to be a polarization low related to simple induced magnetization. The magnetic source may be bounded to the northwest by a southeast-dipping fault, or the magnetic source may have a strong remanent component of magnetization whose inclination and declination are different from that of the Earth's present field. One possible cause for such an anomalous dip of the magnetic field is folding of the source body after magnetization was acquired. Albert (1982) identified a fault on SLAR imagery that trends northeast, parallel to but northwest of the magnetic low. The SLAR lineament is close to the topographic mountain front.

The anomaly along profile $A-A^{\prime}$ (fig. 3) comprises a large high of more than 400 gammas partly over exposed Meshik volcanic rocks, a low in areas underlain by the Meshik, and thin(?) surficial deposits. Some exposed Meshik strata southeast of the main magnetic high have little or no magnetic expression. A simplified two dimensional model was computed along profile $A-A^{\prime}$ using the following assumptions: (1) the magnetization is induced by the Earth's present field (declination $21^{\circ}$, inclination $70^{\circ}$, and intensity of Earth's field $\mathbf{0 . 5 3 6}$ gauss); and (2) the susceptibility of anticlinal body 1 is 0.002 cgs units and the apparent susceptibility of body 2 is $-0.0008 \mathrm{cgs}$ units (reversed remanent magnetization?). As can be seen, the model produces an anomaly that crudely fits the observed profile in amplitude and gradient. Discrepancies between observed and computed profiles are as much as 100 gammas, but it should be noted that on adjacent parallel flight lines anomaly amplitudes commonly differ by more than 100 gammas from those on profile $A-A^{\prime}$. This probably results from variation in susceptibility along strike, which is very common in volcanic rocks. The main points are that the magnetic bodies may extend in depth to as much as $10,000 \mathrm{ft}$, that body 1 may represent an anticlinal structure, and that rocks having reversed magnetization can cause the negative anomaly over body 2 to the northwest.

On trend to the northeast, the Ugashik Lakes anomalies (areas 8A and 8B) are a conspicuous group of anomalies that have amplitudes of 200 to 500 gammas and correlate closely with the thick conglomerates of the Naknek Formation on the southeastern limb of an anticline. The asymmetry of the anomalies, as well as geologic data, indicate a southeast dip of the anticlinal limb. Anomalies in area $8 \mathrm{C}$ have gentler gradients, indicating greater depth to the buried source, and the asymmetry of the anomalies indicates a northwest-dip direction. According to this interpretation, the buried Naknek conglomerate extends to T. 28 S., R. $46 \mathrm{~W}$. (about lat $57^{\circ} 45^{\prime} \mathrm{N}$., long $156^{\circ} 45^{\prime} \mathrm{W}$.), west of the north end of Upper Ugashik Lake, where the anomaly terminates rather abruptly. We speculate that this termination indicates either the position of the Bruin Bay fault or a strand of the fault system, as discussed more fully in a subsequent section.

The offset and the change in strike of anomalies between areas $8 \mathrm{~A}$ and $8 \mathrm{~B}$ coincides approximately with mapped faults that strike northwest.

Magnetic profile $B-B^{\prime}$ across the inferred anticline comprises two highs separated by a large relative low (fig. 4). Using the same parameters for the Earth's field, an anticlinal two-body model was computed. The northwesterndipping body 1 was assumed to have a susceptibility of 0.0025 cgs units, and the southeastern-dipping body 2 was assumed to have a susceptibility of $0.002 \mathrm{cgs}$ units. Thus, we interpret the anomaly to be caused by a breached anticline of Naknek conglomerates and sandstones. The limbs could extend to a depth of $10,000 \mathrm{ft}$ or more, and the northwest limb is somewhat thinner than the southwest limb. A magnetic nose on the southwest end of the anomaly suggests that the anticline may plunge southwest. As along profile $A-A^{\prime}$, the anomaly amplitudes vary greatly on flight lines adjacent to profile $\mathrm{B}-\mathrm{B}^{\prime}$, indicating large changes in susceptibility or source geometry along strike so that a close fit is not warranted.

Farther northeast, in area 9, anomalies range from 200 to 600 gammas. Exposed bedrock units are Quaternary volcanic deposits associated with various centers such as Mount Peulik, Ugashik crater, and Ukinrek maars. The anomalies might be produced by these young volcanic rocks if they have a substantial thickness, but they are somewhat broader than typical anomalies over Quaternary volcanic rocks elsewhere in the region. Because the anomalies are on trend with anomalies related to Naknek conglomerates in area 8 , we believe that such buried Jurassic deposits are the most likely principal source of anomalies in area 9. A third possibility is that the anomalies are produced by largely concealed Jurassic granitoid rocks, one exposure of which occurs on a small island in Becharof Lake northwest of The Gas Rocks (geologic map, sheet 2).

The Mount Peulik-Ugashik crater volcanic center in area 10 is expressed by magnetic highs of as much as 1,400 gammas in amplitude at a position between the two present craters.

\section{Central Mountain Belt}

This belt is characterized by broad open synclines and anticlines. Deeply buried magnetic basement characterizes much of the area, as inferred from gentle magnetic gradients. Small anomalies of 100 to 200 gammas occur over Naknek conglomerates or sandstones, but the amplitudes are generally much lower than over the frontal mountain zone and probably reflect increasing distance of the clastic rocks from magnetite-rich source rocks. In areas where the siltstone facies of the Naknek dominates, few significant anomalies can be seen; the pattern of small high and low anomalies in area 11 probably indicates lenticular concentrations of magnetite within the conglomerates and sandstones, as well as minor terrain effects. Some of the anomalies, however, may be related to small buried plutons or to Quaternary volcanic rocks as in area 11A. Ovoid anomalies in areas 11B occur over the Shelikof and Naknek Formations on the northwest flank of Wide Bay anticline. No igneous rocks have been mapped in the area, so that sedimentary sources are probable.

On the Severson Peninsula in area 12, Naknek conglomerates and sandstones are exposed on the western end, and siltstone is exposed in the central and eastern parts. Prominent magnetic highs of as much as 200 gammas in amplitude indicate that the conglomeratic facies is buried at shallow to moderate depth throughout the length of the peninsula. The westerly trend of the anomaly is somewhat oblique to the inferred northeast trend of fold axes in the area; this discrepancy may reflect channels of magnetic conglomerate.

Near the northeast edge of the map (area 13), small anomalies of about 200 gammas are associated with Quaternary volcanic rocks and are probably produced by flows related to the Kejulik volcanic center in the Katmai quadrangle just north of the map area.

In the southwest part of the Central Mountain belt, magnetic highs of as much as 400 gammas in amplitude are associated with a complex center of Tertiary (Eocene) intrusive and volcanic rocks (area 14) between $W$ andering and Volcano Creeks. This is the site of the Rex gold prospect. The main high is centered over the west-central part of the plutonic complex, but the eastern part of the complex has 
less magnetic expression. Alteration may be suspected in areas of low-amplitude anomalies.

Wide Bay anticline (area 15) is cored with Triassic rocks at depth and by the Jurassic Talkeetna, Kialagvik, and Shelikof Formations. The crestal region is virtually devoid of significant magnetic anomalies.

\section{Southeastern plutonic province}

This province is characterized by many positive anomalies whose amplitudes range from 400 to as much as 2,200 gammas. Many of the anomalies correlate closely with known Tertiary plutons, and some correlate with volcanic rocks. A few anomalies cannot be accounted for by exposed igneous rocks or the Naknek Formation, and they are inferred to be caused by buried plutons. Each of the main anomalies or groups of anomalies will be briefly described from southwest to northeast. A positive anomaly occurs in area 16 over the Tolstoi Formation. Tertiary plutons are exposed just to the southwest in an area of no magnetic data. The source of the magnetic high is inferred to be a concealed pluton buried at very shallow depth. Several small exposures of Tertiary plutons underlie the area of anomaly 17, the site of the Mike molybdenum prospect. Anomaly area 18 coincides closely with the eastern part of a pluton, but the western part is not expressed magnetically. A series of anomalies in area 19 correlates with several plutons, but the most northerly plutons are not magnetically expressed, and alteration may be suspected. Volcanic rocks may cause part of the anomaly in area $19 \mathrm{~A}$.

Anomalies of as much as 400 gammas in area 20 are produced by volcanic rocks of the Mount Chiginagak center and possibly by a concealed pluton. To the northeast, a very large negative anomaly in area 21 has values as low as -800 gammas. Polarization effects may account for part of the anomaly, but the amplitude is so much larger than at Mount Chiginagak proper reversed remanent magnetization of the flow sequences on the north flank of the volcano or a concealed reversely magnetized pluton must be present.

A positive anomaly of 1,400 gammas in area 22 overlies sedimentary rocks, but a pluton is exposed on the north flank of the anomaly, and a shallow concealed extension of the pluton is the likely source.

West of Port Wrangell, Agripina Bay, and Cape Kilokak, a quartz diorite batholithic complex of very late Tertiary age causes positive anomalies of as much as 1,000 gammas in area 23. A southwestern part of the anomaly group overlies the transition between plutonic and volcanic rocks in area $23 \mathrm{~A}$.

A prominent magnetic low of 300 gammas overlies the altered Tertiary volcanic rocks of David Island in area 24.

In area 25, Quaternary volcanic rocks and Tertiary(?) plutons of the intrusive complex at Mount Kialagvik produce anomalies that have amplitudes of as much as 600 gammas.

Anomalies in area 26 are offshore. Inasmuch as the nearest known magnetic sources are batholithic rocks in area 23, a plutonic source is inferred.

On the north side of Imuya Bay, an anomaly of 400 gammas in area 27 may have multiple sources: (1) a small Tertiary pluton crops out on the north flank of the anomaly and (2) Naknek conglomerates (containing boulders as large as $10 \mathrm{ft}$ ) crop out on the south flank of the anomaly. As elsewhere in the area, ground magnetic surveys would be required to determine which rock unit is the principal source.

Small anomalies in area 28 are mainly offshore and their sources are unknown.

Anomalies in area 29 range up to 1,400 gammas. The onland part of the area, north of Cape Igvak, correlates closely with Tertiary quartz diorite plutons. Because of fshore anomalies have amplitudes as high as 1,000 gammas, we believe that their sources are likewise quartz diorite.

\section{Northeastern coastal province}

Rocks in this arbitrarily defined province are principally Mesozoic sedimentary, volcanogenic, and volcanic rocks. Only a few small Tertiary intrusive bodies and a small patch of Quaternary volcanic rocks are exposed. The Shelikof and Naknek Formations of Jurassic age are the most widely exposed in the area. In areas of anomaly 30 , amplitudes range from 100 to 400 gammas principally over exposures of the Shelikof and Kialagvik Formations, but concealed magnetic plutons may be more likely sources.

Several conspicuous negative anomalies of 100 to 400 gammas amplitude comprise areas 31 ; they have no obvious explanation.

A prominent negative anomaly of as much as 200 gammas is present over quartz diorite plutons near Mount Kubugakli (area 32). The plutons are surrounded by hornfels and altered rocks. The negative anomaly extends offshore and probably indicates alteration as well.

Bruin Bay fault

Magnetic anomalies in area 9 cross the projected trace of the Bruin Bay fault, a geologic projection based on the occurrence of Jurassic granodiorite on the small island in Becharof Lake. Anomalies of areas $8 \mathrm{C}$ and 9 appear to terminate along magnetic lineament $\mathrm{X}-\mathrm{X}^{\prime}$. If the geologic projection of the fault is correct, it seems likely that the fault splays into several strands southwest of Becharof Lake and that the magnetically defined strand is parallel to but north of the exposed strand.

\section{Transverse segmentation}

Numerous geologists have observed that the AleutianAlaska Peninsula volcanic arc is segmented along zones transverse to the arc (for example, Fisher and others, 1981; Marsh, 1979, 1982; and Nakamura, 1977). The segmentation is defined by differences in patterns of seismicity, dip of Benioff zones, and by offsets in rectilinear groups of volcanoes. In the Ugashik-Karluk region, a southern line of volcanoes includes Aniakchak Crater (south of map area), Yantarni volcano, Mount Chiginagak, and Mount Kialagvik. The next line to the northeast is the Mount Peulik-Ugashik caldera and the Kejulik volcanic center (north of map area). Fisher and others (1981) identified a northwest-trending zone of discontinuity extending from south of Kodiak Island through the region of Becharof Lake. The lines of volcanoes have an apparent left of fset of about 20 to $30 \mathrm{~km}$, and a gap of about $5 \mathrm{~km}$ is present in which no recognized large volcanic centers occur. Numerous northwest-trending faults have been mapped in the gap between Mount Kialagvik and Mount Peulik (sheet 2), but only a few prominent northwesttrending magnetic lineaments have been observed in the gap. Thus, any arc segmentation is not well expressed by exposed magnetic rocks; the arc segmentation is expressed by Neogene volcanism that does not substantially of fset earlier structural and lithologic trends.

\section{Magnetic anomalies and resource appraisal}

Ten mineralized areas have been defined by S.E. Church (written commun., 1987) in the Ugashik and western part of the Karluk quadrangles. Most of the geochemically anomalous areas are near Tertiary plutonic rocks, their wall rocks, and Tertiary volcanic rocks. The most common geochemical anomalies in stream-sediment samples are copper, molybdenum, silver, lead, and zinc. Many areas also have anomalous amounts of cobalt, nickel, boron, bismuth, arsenic, gold, cadmium, antimony, tungsten, barium, and tin. Minerals in stream sediments include pyrite, chalcopyrite, molybdenite, sphalerite, galena, tourmaline, barite, cinnabar, scheelite, and gold. The area numbers for each of the following ten mineralized areas are from S.E. Church (written commun., 1987).

\section{Rex Prospect (area 1 of S.E. Church)}

This prospect is a porphyry copper-molybdenum system containing gold developed in a hypabyssal dacite. Two magnetic highs of several hundred gammas, separated by a low, occur over the intrusive rocks and the adjacent Tolstoi Formation (area 14, sheet 2). The low is probably due to hydrothermal alteration and hornfelsing. 
Geochemical anomalies of copper, silver, lead, zinc, boron, nickel, and cobalt occur in this area underlain by the Tolstoi Formation that is intruded by small Tertiary plutons. A magnetic high in area 16 (sheet 2) suggests a buried pluton, and a magnetic low to the northwest generally coincides with rock alteration.

Mike prospect (area 3 of S.E. Church)

A large geochemical anomaly of copper and molybdenum is surrounded by drainage basins whose sediments contain anomalous lead, zinc, silver, cadmium, and bismuth. Sills and dikes cut the hornfelsed and altered Naknek Formation and Tertiary volcanic rocks. The prospect occurs on the west flank of a magnetic high of about 400 gammas that is produced by a Tertiary pluton (area 17, sheet 2).

\section{Mount Chiginagak-Chiginagak Bay (area 4 of S.E. Church)}

Geochemical anomalies of copper, molybdenum, tungsten, lead, zinc, cadmium, silver, and arsenic are found south of Mount Chiginagak and eastward to Chiginagak Bay. Magnetic highs of areas 18, 19, and 20 (sheet 2) correlate with Tertiary intrusive and volcanic rocks and with the young volcanic rocks of Mount Chiginagak. Mesozoic and Tertiary sedimentary rocks have heen hornfelsed; the hydrothermal alteration that occurs in some of the Tertiary volcanic rocks appears to have had little effect on the positive anomaly in area $19 \mathrm{~A}$.

Mount Kialagvik to west of the Agripina Bay batholith (areas 5 and 6 of S.E. Church)

Geochemical anomalies of copper, molybdenum, tungsten, lead, zinc, silver, arsenic, bismuth, and gold occur east and southeast of Mount Kialagvik where Mesozoic and Tertiary sedimentary rocks and Tertiary volcanic rocks are altered and hornfelsed in the vicinity of Tertiary intrusive bodies. Magnetic highs in areas 22, 23, 23A, and 25 are produced mainly by the intrusive complex and Tertiary volcanic rocks. Several negative anomalies probably indicate unexposed or unmapped alteration areas.

Portage Bay (area 7 of S.E. Church)

Similar geochemical anomalies, especially molybdenum, silver, zinc, boron, and cobalt, occur in the area from Mount Becharof south to Cape Igvak. A prominent magnetic high of more than 1,000 gammas is produced by the quartz diorite pluton north of Cape Igvak (area 29). Some areas of hornfels and hydrothermal alteration near Cape Igvak were not covered by the magnetic surveys.

Cape Kubugakli (area 8 of S.E. Church)

Geochemical anomalies of molybdenum, copper, boron, gold, tungsten, and cobalt are present in the Cape Kubugakli area. Minor amounts of gold have been produced. The geochemical suites associated with the Tertiary intrusive rocks appear to define both porphyry copper-molybdenum and porphyry molybdenum systems. Mesozoic sedimentary rocks have been extensively hornfelsed around quartz diorite plutons on the cape. A prominent magnetic low (area 32) of about 200 gammas occurs over the cape and extends offshore to the east. Alteration is strongly suggested by the low. Although the area northeast of Puale Bay has few exposed igneous rocks, geochemical anomalies of silver, boron, and molybdenum are found over Mesozoic rocks in the Portage Creek drainages. Small magnetic highs and lows in this part of area 30 (sheet 2) may reflect unexposed intrusive rocks.

West side of Wide Bay (area 9 of S.E. Church)

Scattered geochemical anomalies northwest of Wide
Bay include copper, silver, lead, boron, and barium. No intrusive rocks or alteration zones have been mapped in the area. Small ovoid magnetic highs and lows (50 to 100 gammas) of area 11B (sheet 2) may reflect magnetic phases of the Mesozoic sequences or small scattered plutons.

East of Becharof Lake and north of the Kejulik River (area 10 of S.E. Church)

The area northeast of Becharof Lake and northwest of the Kejulik River is characterized by anomalous copper, silver, and barium. Quaternary volcanic rocks, locally altered, are widely exposed over the Mesozoic sedimentary rocks. Magnetic highs and lows, most having amplitudes of about 100 gammas, are produced by the volcanic rocks.

\section{Other areas}

Geochemical anomalies of molybdenum, copper, and lead were found in rock samples (Wilson, 1986) from David Island, near Port Wrangell, where a conspicuous magnetic low occurs over altered volcanic rocks in area 24. Anomalies of molybdenum, zinc, and silver were reported by wilson from rocks near Cape Kekurnoi (south of Alinchak Bay), on the flank of a magnetic low. Wilson reported anomalies of copper, lead, zinc, and gold from rocks on the south side of Imuya Bay. The geochemical anomalies are in magnetic lows on the north side of area 23.

\section{Summary}

Perhaps the most significant guides to potential mineralization are the ovoid highs of more than 100 gammas in amplitude in areas of known or suspected Tertiary plutons. Magnetic lows related to alteration and hornfelsing constitute a secondary guide. In addition to the magnetic anomalies associated with geochemical anomalies discussed above, magnetic highs in area 27 at the head of Imuya Bay and offshore highs in areas 26 and $29 \mathrm{~A}$ may indicate concealed plutons. Any of the magnetic lows, such as those in areas 31, may indicate alteration zones related to concealed plutons.

\section{Oil and gas}

Within the mountainous region, anticlines, such as the Wide Bay and Ugashik Lake anticlines, are potential targets for oil and gas exploration. Because of virtual absence of magnetic anomalies, the Wide Bay anticline probably contains few igneous bodies. In the Chignik area to the south, the small anomalies in the core of Chignik anticline were thought to be caused by small intrusions, which might indicate a low potential for hydrocarbon production (Case and others, 1981). Now that we have recognized that sedimentary rocks of the Naknek and Shelikof Formations can produce detectable aeromagnetic anomalies, our evaluation of Chignik anticline must be revised to a less pessimistic estimate.

Magnetic anomalies in the Bristol Bay lowlands indicate the depth to the sources is 10,000 to $15,000 \mathrm{ft}$ or more, which agrees with data from deep drill holes. Thus, a large area is underlain by a thick, stratified sequence of rocks that may be potentially favorable for oil and gas exploration.

\section{ACKNOWLEDGMENTS}

We are grateful for the advice and information provided in the field and of fice by J. W. Miller and W. H. Allaway, Jr. William Allaway hand colored part of the original aeromagnetic map to assist in interpretations. Frank Petrafeso merged the two principal sets of aeromagnetic data to produce the contour (sheet 1) map, and Robert Morin made the measurements of magnetic properties. We are grateful to the captain and crew of the R.V. Don J. Miller II for their continuing superb support. Thought ful and helpful review was provided by John Cady and James Riehle. 


\section{REFERENCES}

Albert, N. R. D., 1982, Preliminary maps showing reconnaissance photogeologic interpretation of SLAR imagery of the Bristol Bay, Ugashik, and Karluk quadrangles, Alaska: U.S. Geological Survey Open-File Report $82-141$, scale $1: 250,000,5$ sheets.

Andr easen, G. E., Dempsey, W. J., Vargo, J. L., and others, 1962, Aeromagnetic map of part of the Naknek quadrangle, Alaska: U.S. Geological Survey Geophysical Investigations Map GP-353, scale 1:125,000.

1963, Aeromagnetic map of parts of the Ugashik and Karluk quadrangles, Alaska: U.S. Geological Survey Geophysi cal Investigations Map GP-354, scale 1:125,000.

Barnes, D. F., 1977, Bouguer gravity map of Alaska: U.S. Geological Survey Geophysical Investigations Map GP913 , scale $1: 2,500,000$.

Brockway, Ron, Chairman, 1975, Bristol Bay region, stratigraphic correlation section, southwest Alaska: The Alaska Geologic Society.

Burk, C. A., 1965, Geology of the Alaska Peninsula-island are and continental margin: Geological Society of A merica Memoir 99, $250 \mathrm{p}$.

Case, J. E., Cox, D. P., Detra, D. E., Detterman, R. L., and Wilson, F. H., 1981, Maps showing aeromagnetic survey and geologic interpretation of the Chignik and Sutwik Island quadrangles, Alaska: U.S. Geological Survey Miscellaneous Field Studies Map MF-1053-B, scale $1: 250,000,2$ sheets.

Case, J. E., Tysdal, R. G., Hillhouse, J. W., and Gromme, C. S., 1979, Geologic interpretation of the aeromagnetic map of the Seward and Blying Sound quadrangles, Alaska: U.S. Geological Survey Miscellaneous Field Studies Map MF-880-D, scale 1:250,000, 2 sheets.

Case J. E. and Nelson, W. H., 1986, Maps showing aeromagnetic survey and geologic interpretation of the Lake Clark quadrangle, Alaska: U. S. Geological Survey Miscellaneous Field Studies Map MF-1114-E, scale $1: 250,000,2$ sheets.

Coe, R. S., Globerman, B. R., Plumley, P. W., and Thrupp, G. A., 1985, Paleomagnetic results from Alaska and their tectonic implications, in Howell, D. G., ed., Tectonostratigraphic terranes of the circum-Pacific region: Circum-Pacific Council for Energy and Mineral Resources, no. 1 , p. 85-108.

Detterman, R. L., Case, J. E., Wilson, F. W. Yount, M. E., and Allaway, W. H., Jr., 1983, Generalized geologic map of the Ugashik, Bristol Bay, and part of Karluk quadrangles, Alaska; U.S. Geological Survey Miscellaneous Field Investigations Map MF-1539-A, scale 1:250,000.

-1987 , Geologic map of the Ugashik, Bristol Bay, and western part of Karluk quadrangles, Alaska; U.S. Geological Survey Miscellaneous Investigations Map I1685 , scale $1: 250,000$.

Detterman, R. L., and Reed, B. L., 1980, Stratigraphy, structure, and economic geology of the Iliamna quadrangle, Alaska: U.S. Geological Survey Bulletin $1368-\mathrm{B}, 86 \mathrm{p}$.

Fisher, M. A., Bruns, T. R., and von Huene, Roland, 1981, Transverse tectonic boundaries near Kodiak Island, Alaska: Geological Society of A merica Bulletin, v. 92, no. 1 , Pt. 1, p. 10-18.
Grauch, V. J. S., and Campbell, D. L., 1984, Does draping aeromagnetic data reduce terrain-induced effects? Geophysics, v. 49, no. l, p. 75-80.

Griscom, Andrew, 1975, Aeromagnetic map and interpretation of the Nabesna quadrangle, Alaska: U.S. Geological Survey Miscellaneous Field Studies Map MF$655-M$, scale $1: 250,000,2$ sheets.

Griscom, Andrew, and Case, J. E., 1982, Magnetic expression of geologic terranes in southern Alaska [abs.]: Society of Exploration Geophysicists, Technical Program, Abstracts and Biographies, 52nd Annual Meeting, p. 230232; also in Geophysics, v. 48, no. 4, p. 444-445.

Hanson, B. M., 1957, Middle Permian limestone on Pacific side of Alaska Peninsula: American Association of Petroleum Geologists Bulletin, v. 41, p. 2376-2378.

Marsh, B. D., 1979, Island-arc volcanism: American Scientist, v. 67 , no. 2 , p. $161-172$.

1982, The Aleutians, in Thorpe, R. S., ed., Andesites, New York, John Wiley and Sons, p. 100-114.

Nakamura, Kazuaki, 1977, Volcanoes as possible indicators of tectonic stress orientation-principle and proposal: Journal of Volcanology and Geothermai Research, v. 2, no. 1 , p. 1-16.

Panuska, B. C., and Stone, D. B., 1985, Latitudinal motion of the Wrangellia and Alexander terranes and the southern Akaska superterrane, in Howell, D. G., ed., Tectonostratigraphic terranes of the Circum-Pacific region: Circum-Pacific Council for Energy and Mineral Resources, Earth Science Series, no. 1, p. 109-120.

Reed, B. L, and Lanphere, M. A., 1973, Alaska-Aleutian Range batholith: geochronology, chemistry, and relation to circum-Pacific plutonism: Geological Society of America Bulletin, v. 84, p. 2583-2610.

Reed, B. L., Lanphere, M. A., and Miesch, A. T., 1983, plutonic rocks of Jurassic age in the Alaska-Aleutian Range batholith: Chemical variations and polarity: Geological of America Bulletin, v. 94, no. 10, p. 12321240.

Stone, D. B., and Packer, D. R., 1979, Paleomagnetic data from the Alaska Peninsula: Geological Society of A merica, Part I, v. 90 , p. $545-560$.

Stone, D. B., Panuska, B. C., and Packer, D. R., 1982 , Paleolatitudes versus time for southern Alaska: Journal of Geophysical Research, v. 87, no. B5, p. 3697-3707.

Sweet, J. M., 1964, Developments in Alaska in 1963: American Association of Petroleum Geologists Bulletin, V. 48. no. 6, p. 1035-1049.

Thrupp, G. A., and Coe, R. S., 1983, Preliminary resul ts of a paleomagnetic study of Alaska Peninsula rocks [abs.]: EOS, American Geophysical Union Transactions, v. 64, p. 688 .

Thrupp, G.A., 1984, Paleomagnetism of Teriary volcanic rocks from the Alaska Peninsula: is the Peninsular terrane a coherent tectonic entity? [abs.]: Geological Society of America Abstracts with Program, v. 16, no. 5, p. 337 .

U. S. Geological Survey, 1984, Aeromagnetic map of parts of the Ugashik and Karluk $1^{\circ} \times 2^{\circ}$ quadrangles, Alaska: U. S. Geological Survey Open-File Report 84-351, scale $1: 250,000,2$ sheets. 
Wilson, F. H., 1978, Map showing preliminary results of K-Ar studies in the Chignik and Sutwik Island quadrangles, Alaska: U. S. Geological Survey Open-File Report 781064 , scale $1: 250,000$.

Wilson, F. H., 1980, Late Mesozoic and Cenozoic tectonics and the age of porphyry copper prospects: Chignik and Sutwik Island quadrangles, Alaska Peninsula: U. S. Geological Survey Open-File Report 80-543, 94 p.

Wilson, F. H., Baum, W. C., and Herzon, P. L. 1981, Map and tables showing geochronology and whole-rock geochemistry, Chignik and Sutwik Island quadrangles, Alaska: U. S. Geological Survey Miscellaneous Field Studies Map MF-1053-M, scale 1:250,000, 3 sheets.

Wilson, F. H., and O'Leary, R.M., 1986, Maps and tables showing data and analyses of semiquantitative emission spectometry and atomic-absorption spectrophotometry of rock samples, Ugashik, Bristol Bay, and part of Karluk quadrangles, Alaska: U. S. Geological Survey Miscellaneous Field Studies Map MF-1539-C, scale $1: 250,000,3$ sheets.

Wilson F. H., and Shew, Nora, 1982, Preliminary results of potassium-argon age determinations from the Ugashik quadrangle, Alaska Peninsula, in Coonrad, w. L., ed., The United States Geological Survey in Alaska-Accomplishments during 1980: U. S. Geological Survey Circular 844, 86-87.

in press, Map and tables showing geochronology and whole-rock geochemistry of selected samples from the Ugashik, Bristol Bay, and part of Karluk quadrangles, Alaska: U.S. Geological Miscellaneous Field Studies Map MF-1539-E, scale $1: 250,000,4$ sheets. 


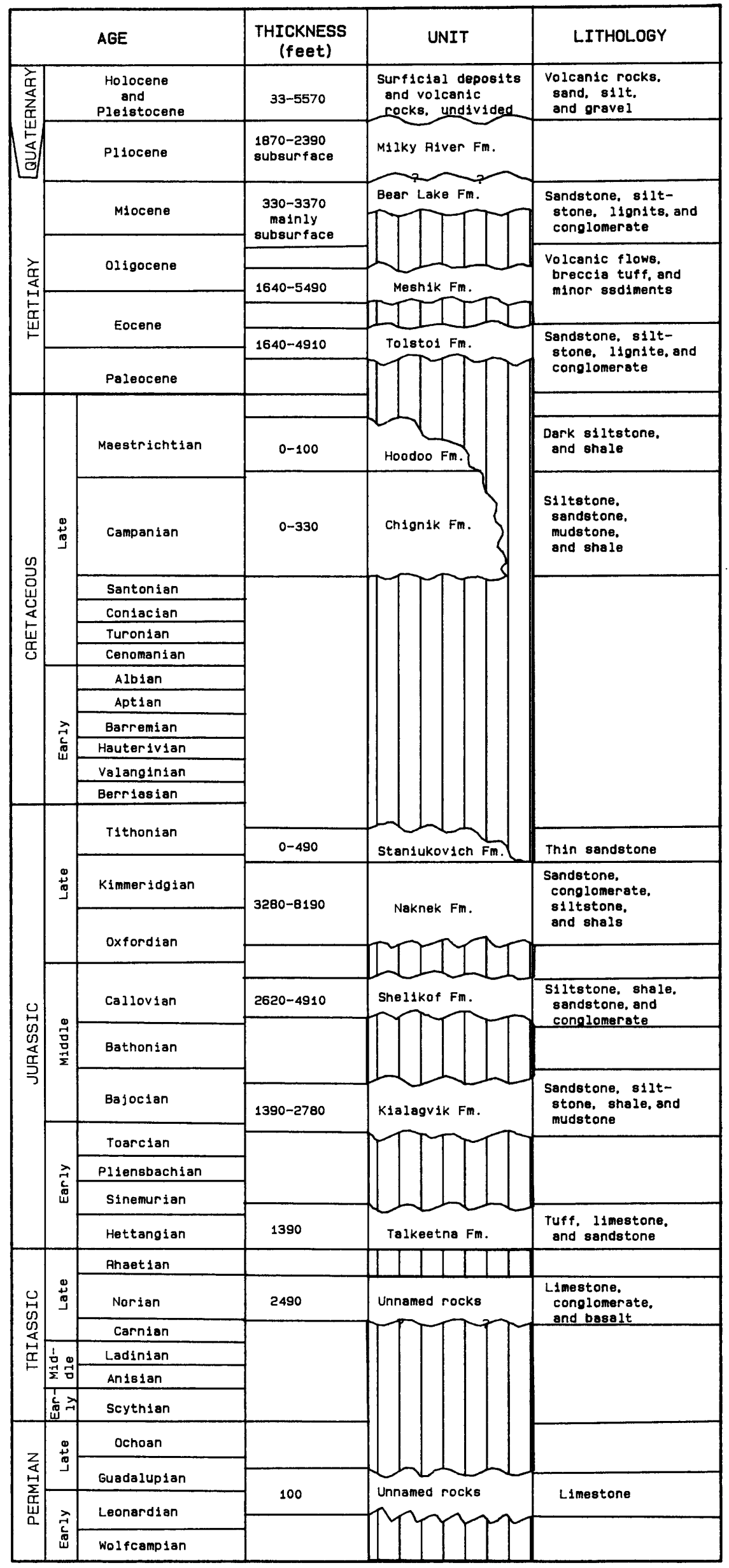

Figure 1. - Summary of thickness, lithology, and age of major rock units in the Ugashik and Karluk quadrangles, Alaska. Modified from Burk (1965), Brockway (1975), and Detterman and others (1983). Wavy lines indicate unconformities. 


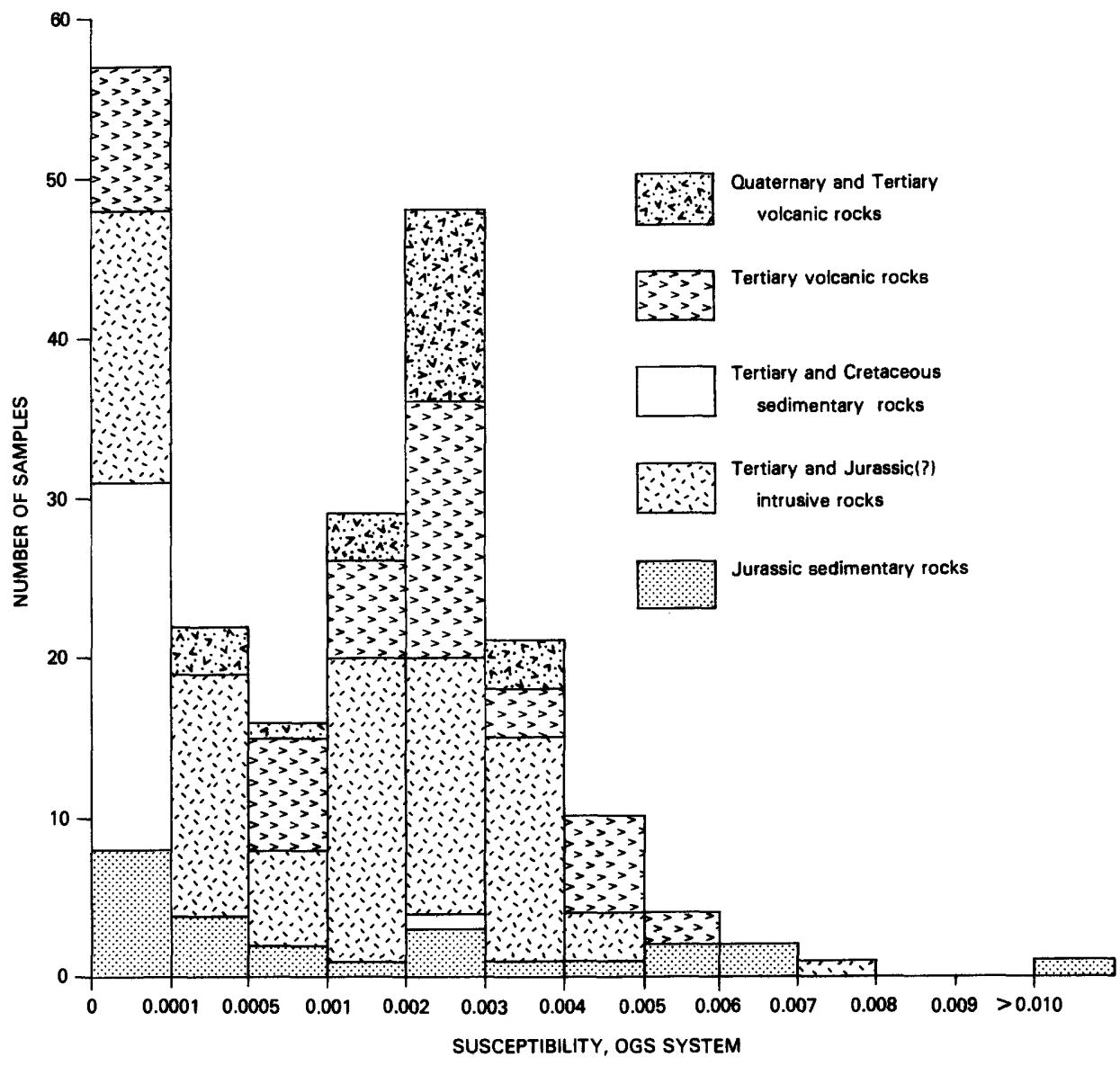

Figure 2. - Magnetic susceptibilities of rock samples from the Ugashik and Karluk quadrangles and vicinity, Alaska. 

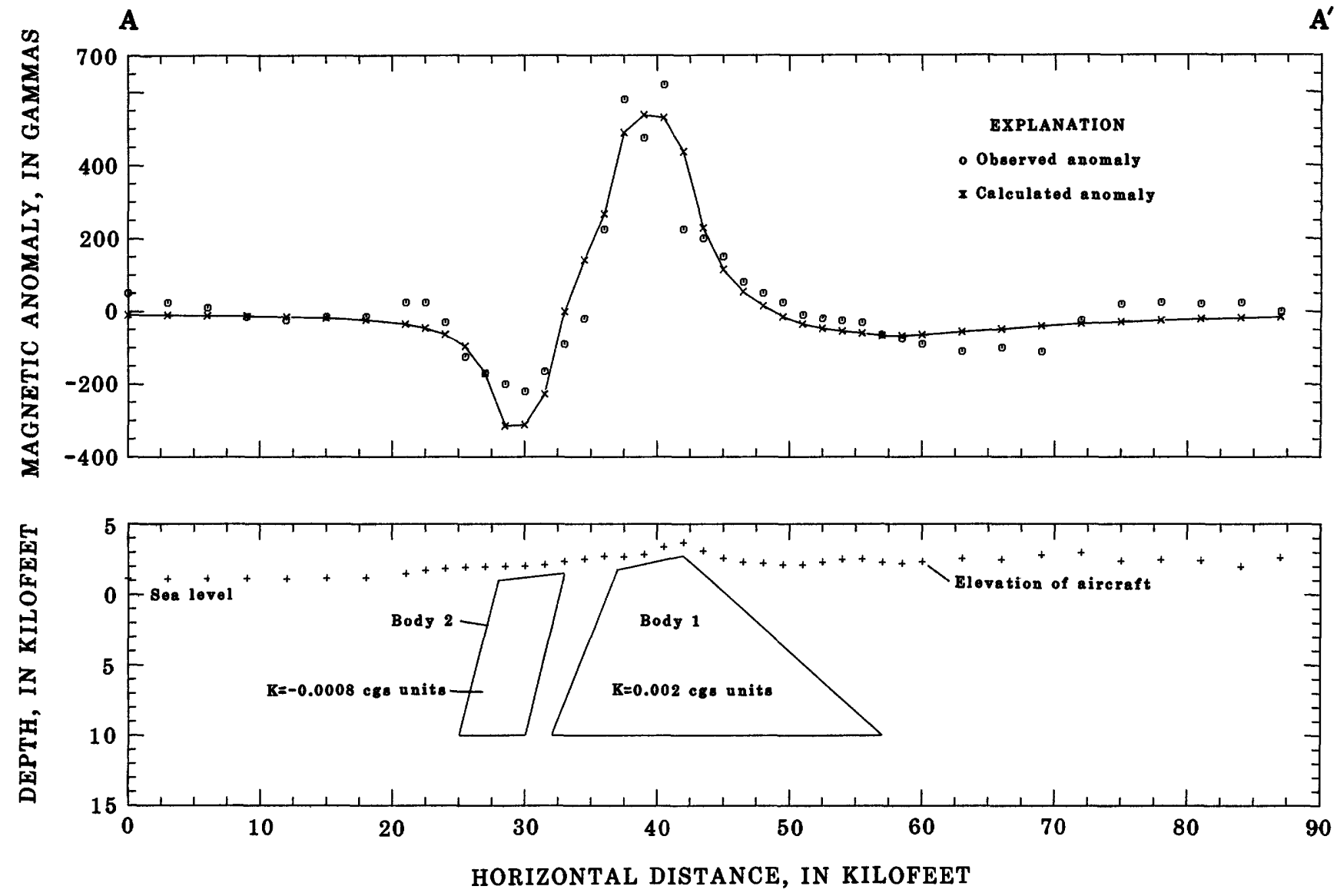

Figure 3. - Interpretation of magnetic anomalies along profile A - A'. K, magnetic susceptibility. Observed anomalies from detailed maps (U.S. Geological Survey, 1984). 

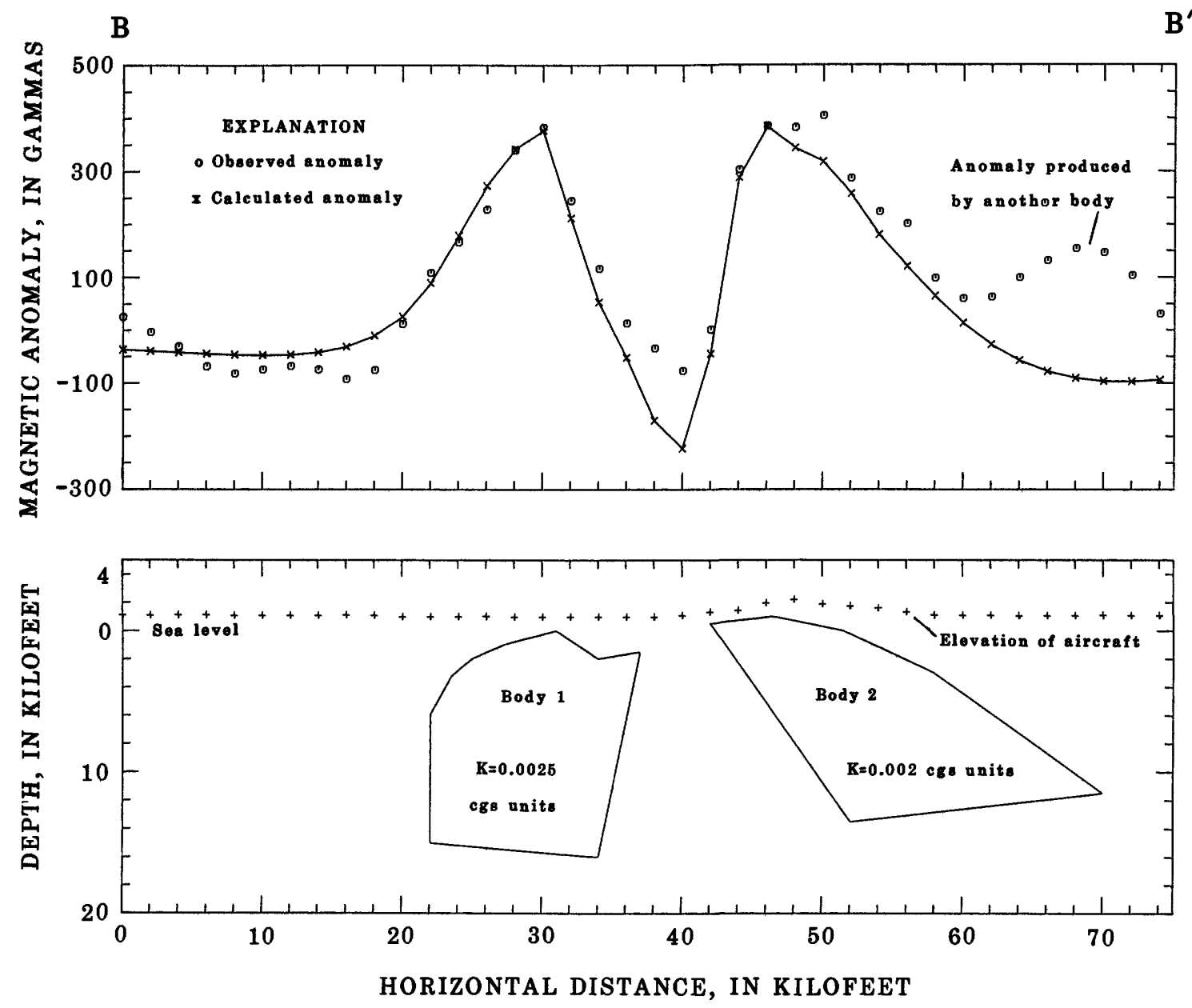

Figure 4. - Interpretation of magnetic anomalies along profile B - B'. K, magnetic susceptibility. Observed anomalies from detailed maps (U.S. Geological Survey, 1984). 